\title{
ДО ЮВІЛЕЮ ТАЛАНОВИТОГО НАУКОВЦЯ, ПЕДАГОГА І ЛІКАРЯ КАТЕРИНИ ІГОРІВНИ БОДНІ
}

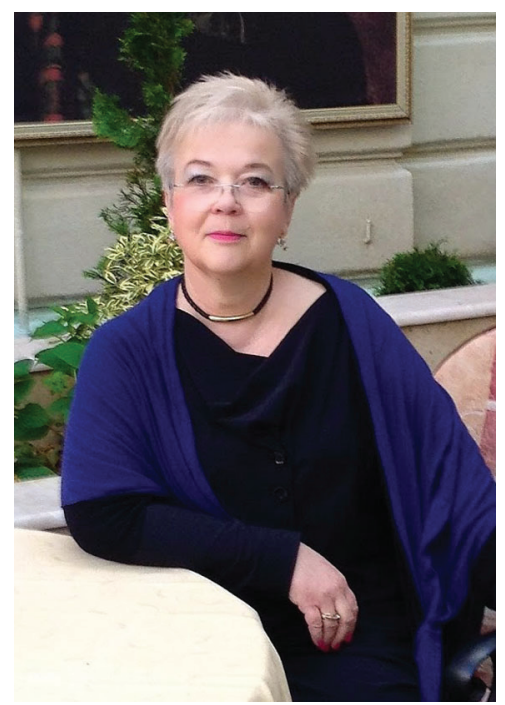

Стисло висвітлено основні біографрічні віхи й творчий доробок професора К.І. Бодні - відомого лікаря-паразитолога, педагога, науковця, заслуженого діяча науки та техніки України, завідувачки кафедри медичної паразитології та тропічних хвороб Харківської медичної академії післядипломної освіти.

В 1980 р. Катерина Ігорівна Бодня закінчила лікувальний фракультет Харківського державного медичного інституту з відзнакою за спеціальністю «лікувальна справа».

Після закінчення інституту навчалася у клінічній ординатурі, а потім в аспірантурі з гастроентерології. Після захисту кандидатської дисертації у 1985-1988 рр. працювала асистентом кафредри медичної паразитології Українського інституту вдосконалення лікарів, у 1988-2000 рр. - доцентом, 2000-2001 рр. - профресором, з 2001 р. - завідувачка цієї кафредри.

Кандидатську дисертацію виконала на тему: «Вміст гонадотропних гормонів гіпосрізу, статевих гормонів, гастрину і цАМФ у крові при виразковій хворобі дванадцятипалої кишки» (1986), докторську дисертацію - «Порушення процесів адаптації та їх корекція при хронічному опісторхозі» (1999).

К.І. Бодня - Заслужений діяч науки та техніки України (2015). Ії̈ стаж педагогічної роботи у вищих навчальних закладах освіти IV рівня акредитації становить 37 років - усі в Харківській медичній академії післядипломної освіти.
К.І. Бодня пройшла в академії шлях від аспіранта до професора та завідувача кафедри. 3 перших кроків трудової діяльності ввійшла в одну із самих авторитетних медичних наукових шкіл, з якої вийшли відомі вчені академік М.М. Соловйов, профресор Є.С. Шульман, професор Р.Г. Лукшина. Будучи молодим фрахівцем, К.І. Бодня перейняла від вчителів любов до постраждалої людини, готовність віддати себе боротьбі за її здоров'я, а також уміння використовувати набуті знання для вирішення складних наукових і практичних проблем.

Профресор К.І. Бодня очолює єдину в Україні кафредру медичної паразитології та тропічних хвороб, на якій проводяться цикли удосконалення лікарів з актуальних питань медичної та клінічної паразитології, цикли передатестаційної підготовки та спеціалізації за фрахом паразитологія, тематичного удосконалення 3 медичної паразитології та тропічних хвороб. Для лаборантів клініко-діагностичних лабораторій та лікарів лікувального профрілю проводяться цикли тематичного удосконалення з усіх розділів медичної паразитології. Касредра медичної паразитології є опорною зі спеціальності «паразитологія». Профресор Бодня К.І. $€$ членом навчально-методичної ради ХМАПО з опорних кафредр і користується великим авторитетом.

Лекції Бодні К.І. базуються на багаторічному особистому науковому та практичному досвіді з діагностики та лікування паразитарних хвороб, на останніх даних вітчизняних та зарубіжних публікацій. Зміст лекцій підкріплюється ілюстративними матеріалами: слайдами, малюнками, плакатами і демонстрацією хворих. Просресор К.І. Бодня є досвідченим та широко відомим фрахівцем в Україні та державах зарубіжжя з паразитарних хвороб, порушень процесів адаптації та їх корекції при опісторхозі та інших гельмінтозах.

В останні роки кафедра активно готує наукових працівників із числа практичних лікарів. У 2003 р. за ініціативи К.І. Бодні була відкрита аспірантура за спеціальністю паразитологія, гельмінтологія. Під її керівництвом захищено 10 дисертаційних робіт (1 докторська та 9 кандидатських), виконуються 2 докторські дисертації та 5 кандидатських.

Каседра проводить велику лікувально-діагностичну роботу в ділянці медичної паразитології, виконує фрункції центру з діагностики і лікування паразитарних хвороб. Профессор К.І. Бодня особисто надає консультативну допомогу лікарям, особливо з питань діагностики паразитозів, епідеміологічного аналізу та інших актуальних проблем. 


\section{ЮВІЛЕї ТА ПОДІї}

Основні напрямки наукових досліджень на кафедрі такі: патогенез, клініка та лікування гельмінтозів; експериментальне та клінічне вивчення нових антигельмінтиків; питання імунітету та алергії у хворих на паразитози; епідеміологія та профрілактика опісторхозу, демодекозу, ентеробіозу, лямбліозу, токсоплазмозу, токсокарозу та ін.; вплив антропогенного фрактора на компоненти гнусу. Отримані нові дані впроваджуються у практичну діяльність лікувальних установ України.

Перспективним напрямком роботи кафедри є подальше вивчення порушень процесів адаптації при паразитарних інвазіях та їх корекція, розробка пропозицій для практики охорони здоров'я, подальша оптимізація навчального процесу з використанням результатів власних наукових досліджень і досягнень світової науки.

К.І. Бодня $€$ автором більше 500 публікацій, має 30 авторських свідоцтв на винаходи. Вона постійно вдосконалює свою лікарську і педагогічну майстерність, підвищує свій профресійний рівень. Наукову, навчальну і лікувальну роботу Катерина Ігорівна успішно поєднує з активною суспільною діяльністю. Вона була вченим секретарем Харківського медичного товариства (2003-2014рр.), головою Харківського товариства паразитологів. Протягом двох років (1987-1989 рр.) виконувала обов'язки заступника декана медико-профілактичного фракультету ХМАПО, потім тривалий час працювала деканом цього ж факультету (2003-2017рр.), головний позаштатний спеціаліст МО3 України зі спеціальності «паразитологія» (з 2007 р.).

Профресор К.І. Бодня - багатолітній член Всеукраїнської асоціації інфекціоністів, учасник багатьох науковопрактичних консеренцій, пленумів і з'їздів цієї авторитетної профресійної громадської організації.

Бажаємо вельмишановній Катерині Ігорівні Бодні міцного здоров'я і нових творчих успіхів у науковій, педагогічній та лікарській діяльності.

Президія ГО «Всеукраїнська асоціація інфрекціоністів», ректорат і колектив ХМАПО

\section{TO THE ANNIVERSARY OF A TALENTED SCIENTIST, TEACHER AND PHYSICIAN KATERYNA IHORIVNA BODNIA}

SUMMARY. Basic biographic landmarks and creative work of professor K.I. Bodnia are briefly reflected. She is a doctor-parasitologist, teacher, scientist, honoured worker of scitech Ukraine, head of Medical Parasitology and Tropical IIInesses Department of the Kharkiv Medical Academy of Postgraduate Education.

Отримано 13.09.2017 p. 